\title{
Urgensi Self Efficacy Konselor Sekolah dalam Mengembangkan Pendidikan Karakter Siswa (Penelitian Survey terhadap konselor Sekolah di Kota Malang)
}

\author{
Erik Teguh Prakoso \\ erikteguh@ymail.com \\ Universitas Kanjuruhan Malang \\ Esa Nur Wahyuni \\ esa aminuddin@yahoo.com \\ Universitas Kanjuruhan Malang
}

\begin{abstract}
Abstrak
Tujuan jangka panjang yang ingin dicapai melalui penelitian ini adalah upaya mengembangkan tingkat eficasy konselor sekolah dalam pendidikan karakter di Kota Malang. Dengan merancang dan menerapkan Strategi efficacy dalam pendidikan karakter yang tepat, tingkat efficacy yang ada dalam diri konselor akan tercapai secara maksimal. Tujuanya adalah menjelaskan tingkat self efficacy konselor sekolah di Kota malang dalam mengembangkan pendidikan karakter yang efektif. Penelitian ini dilakukan selama 2 (dua) tahun. Pada tahun pertama dilakukan kegiatan sebagai berikut: 1) persiapan pembuatan instrument, 2) menganalisis tingkat efficacy konselor di sekolah, 3) menganalisis teori-teori yang mendukung pemecahan masalah self efficasy, dan 4) mendesain Strategi efficasy yang cocok digunakan untuk mengembangkan pendidikan karakter. Sampel penelitian dipilih secara purposive random sampling. Instrumen penelitian yang digunakan adalah pedoman Observasi, pedoman wawancara dan questioner dalam bentuk penelitian survey dengan kajian pustaka. Pada tahun kedua penelitian ini, dilakukan ujicoba peningkatan self efficacy dalam pendidikan karakter bagi konselor sekolah di Kota Malang. Disain penelitian yang digunakan adalah penelitian survey dengan pendekatan kuantitatif deskriptif. Dalam penelitian ini penelitian survey dipilih karena dianggap paling efektif dan effisien untuk mendapatkan data yang tepat, cepat dan akurat tentang informasi Self Efficacy Konselor dalam mengembangkan pendidikan karakter siswa di Jawa Timur.
\end{abstract}

Kata Kunci: Self Efficacy, Konselor Sekolah, Pendidikan Karakter

\section{PENDAHULUAN}

Karakter merupakan suatu fondasi kehidupan bangsa. Karakter bagi suatu bangsa memiliki fungsi memberikan arah kemana bangsa harus menuju, bagaimana cara mencapai tujuan itu, apa yang harus dikaji dan dipegang teguh dan sebaliknya apa yang harus dihindari dan dibuang jauh-jauh. Suatu bangsa akan runtuh manakala tidak mempunyai karakter yang kuat. Untuk menjadi bangsa yang maju, modern dan beradab maka diperlukan karakter yang kuat (Zamroni, 2011).

Karakter yang kuat suatu bangsa harus nampak dalam karakter individu setiap warga bangsa dan diwariskan dari satu generasi ke generasi berikutnya lewat pendidikan. Hal ini mempunyai makna bahwa karakter yang kuat tidak akan secara otomatis tumbuh dan berkembang dalam diri masyarakat, sebagaimana generasi-generasi sebelumnya. Di sekolah pendidikan karakter merupakan proses mengembangkan dalam diri siswa sebuah pemahaman, komitmen, dan kecenderungan untuk berperilaku sesuai dengan nilai-nilai etika (Milson and Mehlig, 2002).

Pendidikan karakter mempunyai makna lebih tinggi dari pendidikan moral, karena bukan sekedar mengajarkan mana yang benar dan mana yang salah. Lebih dari itu pendidikan karakter menanamkan kebiasaan (habituation) tentang hal yang baik sehingga siswa didik menjadi mengerti (kognitif) tentang mana yang baik dan salah, mampu merasakan (afektif) nilai yang baik dan mau melakukannya (psikomotor). 
Pengembangan karakter bagi siswa merupakan proses yang tidak mungkin dilakukan dengan secara instan dan segera dapat diukur hasilnya. Oleh karena itu, seorang konselor harus memiliki kegigihan dan motivasi yang tinggi untuk melaksanakan tugas mengembangkan karakter positif tersebut. Kegigihan dan motivasi sangat terkait dengan konstruk rasa efikasi diri (self efficacy) di mana rasa efikasi yang tinggi cenderung mendorong konselor untuk berusaha keras membimbing dengan sebaikbaiknya, meskipun dalam situasi-situasi yang menghambat (Gibson \& Dembo, 1984, dalam Milson, 2002).

Larson dan daniels (1998) mendefinisikan efikasi diri konselor sebagai keyakinan atau penilaian terhadap kemampuan mereka dalam memberikan layanan bimbingan konseling yang efektif kepada siswa. Sedangkan Suton dan Fall (1995) mendefinisikan efikasi diri konselor sebagai keyakinan-keyakinan yang didasarkan pada harapan individu bahwa dia memiliki pengetahuan dan keterampilan, kemampuan untuk mengambil tindakan yang dibutuhkan untuk memecahkan problem yang dihadapinya serta akan berhasil hidupnya walaupun dalam kondisi dalam tekanan.

Sama seperti guru, dalam efikasi diri konselor sekolah terdiri atas dua komponen, yaitu effikasi konselor yang bersifat personal dan effikasi konselor yang bersifat umum (Gibson \& Dembo, 1984, dalam Milson, 2002). Efikasi konselor yang bersifat personal adalah keyakinan konselor bahwa dirinya memiliki kemampuan untuk melaksanakan layanan bimbingan dan konseling. Kemampuan tersebut antara lain 1) kemampuan membangun hubungan harmonis dengan siswa, 2) mampu melakukan konfrontasi dan menantang siswa, 3) memiliki kepekaan secara emosional, 4) mampu merancang dan melakasanakan intervensi secara efektif (bermakna sebagai konselor. Sedangkan efikasi secara umum berkaitan dengan keyakinan seorang konselor bahwa faktor lingkungan yang menentukan keberhasilannya. Misalnya seorang konselor yang berhasil mengubah perilaku tidak sesuai menjadi sesuai, karena dia memiliki kemampuan untuk memberikan perlakuan atau bimbingan (efikasi personal).
Tinggi rendahnya efikasi diri mengemban tugas tersebut akan menentukan konselor sebagai figure berkarakter (a person of character) yang dapat menjadi teladan bagi anak didiknya untuk berperilaku jujur, suka menolong, dan tanggung jawab, yang merupakan sebagian dari karakter mulia. Rendahnya efikasi diri konselor dalam mengembangkan karakter siswa akan berpengaruh terhadap keberhasilan pendidikan karakter. Beberapa penelitian tentang efikasi menunjukkan bahwa efikasi diri sebagai faktor penting dalam keberhasilan konselor memberikan layanan bimbigan dan konseling (Barbee, Scherer \& Combs, 2003; Lent, Hoffman, \& Hill, 2006; Perrone, Perrone, Chan, \& Thomas, 2000; Holcomb-McCoy, Harris, Hines, \& Johnston, 2008).

Selain sebagai kota pariwisata, Malang juga menjadi kota pendidikan. Dari Pusat Data Statistik Pendidikan (PDSP)Kemendikbud Indonesia diketahui jumlah sekolah dari jenjang Sekolah dasar sampai dengan sekolah menengah atas sebanyak 612 sekolah baik negeri maupun swasta yang terdiri dari SD/MI (268), SMP/MTs (98), SMA/MA (44), dan SMK (43). Sedangkan di kabupaten Malang memiliki sekitar SD/MI (1101), SMP/MTs (304), SMA/MA (62), dan SMK (78) (http://npsn.data.kemdiknas.go.id). Berdasarkan pada data-data tersebut, maka pengambangan pendidikan karakter untuk siswa menjadi program yang sangat penting. Untuk keberhasilan program pengembangan karakter siswa, maka konselor sekolah sebagai salah satu professional yang bertanggungjawab terhadap pencapaian tujuan pendidikan menjadi sangat relevan dan strategis. Konselor sekolah yang memiliki efikasi diri tinggi akan memiliki keyakinan, motivasi, dan usaha untuk dapat mengembangkan karakter siswa.

Mempertimbangkan pentingnya efikasi konselor dalam mengembangkan pendidikan karakter, maka penelitian tentang efikasi diri konselor sekolah dalam Mengembangkan Pendidikan Karakter siswa ini ingin mengetahui tingkat efikasi konselor sekolah dalam mengembangkan pendidikan karakter. Penelitian ini akan membidik konselorkonselor sekolah yang ada di wilayah Kota Malang. 


\section{METODOLOGI}

Untuk menjawab pertanyaan penelitian yang ingin mengetahui Urgensi Self Efficacy Konselor sekolah dalam Mengembangkan Pendidikan Karakter Siswa Penelitian Survey Kepada Konselor sekolah di Kota Malang, maka metode penelitian yang dipilih adalah sebagai berikut;

A. Untuk menjawab pertanyaan penelitian ini, maka akan dipilih rancangan penelitian survey dengan pendekatan kuantitatif deskriptif, Penelitian survey adalah penelitian yang mengambil sample dari satu populasi dan menggunakan kuisioner sebagai alat pengumpul data yang pokok (Singarimbun, 1998).

B. Ada tiga variabel dalam penelitian ini, yaitu self efficacy konselor, Pendidikan karakter, dan Konselor sekolah.

1. Self-Efficacy konselor adalah keyakinan konselor akan kemampuannya sebagai konselor untuk menjalankan tugasnya.

2. Pendidikan karakter adalah proses pengembangan pemahaman, komitmen, dan kecenderungan untuk bertindak sesuai dengan nilai-nilai moral yang berlaku.

3. Konselor Sekolah adalah konselor yang bertugas untuk menyampaikan materi-materi keislaman di madrasah.

\section{Subyek Penelitian}

Subyek penelitian dalam penelitian ini adalah para Konselor sekolah yang ada di wiayah Kota Malang.

\section{Instrumen Penelitian}

Instrumen yang digunakan dalam penelitian ini adalah Quistioner yang berupa angket. Angket yang dibuat merupakan angket tertutup dengan menggunakan skala likert. Sebelum digunakan angket tersebut akan diuji coba kepada Konselor sekolah di wilayah Kota Malang dan sekitarnya untuk mendapatkan kualitas angket yang bisa dipertanggungjawabkan.

Angket pengukuran self efficacy konselor dalam penelitian survey ini diadaptasi dari skala pengukuran self efficacy konselor yang dikembangkan oleh Milson dan Mehlig (2012).

Dua komponen utama, yaitu komponen pengukur persona self efficacy konselor dan general efficacy konselor. Tabel 1.1 Menjelaskan item-item skala self efficacy konselor sekolah dalam mengembangkan pendidikan karakter untuk siswa.

Tabel 1.1 Kisi-kisi Instrumen Skala Self efficacy Konselor

\begin{tabular}{|l|l|}
\multicolumn{2}{|c|}{ Sub Variabel Self efficacy Konselor } \\
\hline Persona self efficacy & $1,3,6,7,8,11,14,17,19,21,22,23$ \\
\hline General self efficacy & $2,4,5,9,10,12,13,15,16,18,20,24$ \\
\hline
\end{tabular}

\section{E. Pengumpulan Data}

Pengumpulan data dilakukan dengan cara menyebarkan angket kepada para konselor sekolah melalui Musyawarah Guru Bimbingan Konseling (MGBK) di wilayah Kota Malang.

\section{F. Analisa Data}

Data yang telah diperoleh dalam penelitian ini akan di analisis dengan menggunakan analisis statistik deskriptif yang memanfaatkan software SPSS for Windows 18. Dari hasil analisis data tersebut akan didapatkan nilai yang menunjukkan tingkat Self -Efficacy konselor sekolah mengembangkan pendidikan karakter di Kota Malang.

\section{HASIL DAN PEMBAHASAN}

\section{A. Karakteristik Demografik Konselor}

Tabel 1.2. menunjukkan data tentang karakteristik konselor sekolah di Kota Malang yang telah dikumpulkan dan dianalisa. Responden yang menjadi sampel dalam penelitian survey ini sebanyak 50 orang responden. 
Tabel 1.2. Karakteristik Demograpik Konselor

\begin{tabular}{|c|c|c|}
\hline Variabel & \multicolumn{2}{|c|}{ Sampel } \\
\hline $\begin{aligned} & \text { Jender } \\
& \bullet \text { Laki-laki } \\
& \text { - } \text { Perempuan } \\
&\end{aligned}$ & $\begin{array}{l}13 \\
37\end{array}$ & $\begin{array}{l}26 \% \\
74 \%\end{array}$ \\
\hline $\begin{aligned} \text { Usia } & \\
\bullet & 25-30 \\
\bullet & 31-40 \\
\bullet & 41-50 \\
\bullet & 51-55\end{aligned}$ & $\begin{array}{l}5 \\
24 \\
15 \\
6\end{array}$ & $\begin{array}{l}10 \% \\
48 \% \\
30 \% \\
12 \%\end{array}$ \\
\hline $\begin{aligned} & \text { Pendidikan } \\
& \text { - } \text { SMA } \\
& \text { - } \text { Diploma } \\
& \text { - } \text { Sarjana }\end{aligned}$ & $\begin{array}{l}7^{-} \\
43\end{array}$ & $\begin{array}{l}0 \% \\
13 \% \\
47 \%\end{array}$ \\
\hline $\begin{array}{cl}\text { Jenjang Satuan Pendidikan } \\
\text { - } & \text { SD } \\
\text { - } & \text { SMP } \\
\text { - } & \text { SMA/SMK }\end{array}$ & $\begin{array}{l}8 \\
18 \\
24\end{array}$ & $\begin{array}{l}16 \% \\
36 \% \\
48 \%\end{array}$ \\
\hline
\end{tabular}

Dari data pada tabel 1.2 tersebut dapat diketahui bahwa secara gender jumlah konselor laki-laki (13 orang atau sekitar 26\% dari total responden) lebih sedikit dibandingkan konselor perempuan (47 orang atau $74 \%$ ). Sedangkan dari sisi usia sebanyak 5 (10\%) orang berusia antara 25-30 tahun, $24(48 \%)$ orang berusia 31-40 sebanyak 7 (13\%) orang memiliki jenjang pendidikan diploma sedangkan 43( 87\%) adalah jenjang pendidikan di tingkat sarjana. Ditinjau dari jenjang satuan pendidikan terdapat $8(16 \%)$ responden bertugas sebagai konselor di sekolah dasar (SD), 18 (36\%) responden adalah konselor di Sekolah Menengah Pertama (SMP); sedangkan sisnya $24(48 \%)$ responden merupakan konselor di Sekolah menengah Atas (SMA) dan Sekolah Menengah Kejuruan (SMK).

\section{B. Tingkat Selff efficacy Konselor Sekolah.}

Tingkat self efficacy konselor dalam mengembangkan pendidikan karakter untuk siswa dapat diketahui dari jumlah skor jawaban responden penelitian survey ini. Secara umum tingkat self eficacy konselor dilihat dari skor persona self efficacy konselor dan general self efficacy konselor. Sesuai kriteria, respon dari responden terhadap skala self efficacy konselor adalah sangat setuju (5); stuju (4), Tidak tahu (3), Tidak setuju (2), dan sangat tidak setuju (1). Tabel 4.2 dan 4.3 menjelaskan distribusi responden terhadap skala self efficacy konselor baik pada komponen persona self efficacy mapun general self efficacy.

B.1. Tingkat Selff efficacy Konselor Sekolah.

Tabel 2.1. Distribusi respon konselor untuk komponen persona self efficacy

\begin{tabular}{|c|c|c|c|c|c|c|}
\hline No & Pernyataan & SS & $\mathbf{S}$ & TT & TS & STS \\
\hline 1 & $\begin{array}{l}\text { Saya merasa nyaman membicarakan tentang perilaku baik dan } \\
\text { buruk dengan murid-murid saya. }\end{array}$ & 73 & 23,5 & 1.6 & 0.8 & 0.8 \\
\hline 2 & $\begin{array}{l}\text { Ketika seorang siswa telah dikenal sabagai anak yang nakal karena } \\
\text { pengaruh lingkungan di rumahnya, saya tidak yakin akan dapat } \\
\text { membangun karakternya. }\end{array}$ & 1.2 & 5.6 & 11.6 & 46.2 & 35.5 \\
\hline 3 & $\begin{array}{l}\text { Saya sangat yakin telah menjadi contoh yang baik bagi murid- } \\
\text { murid saya. }\end{array}$ & 77.3 & 21.9 & 0.8 & 0.0 & 0.0 \\
\hline 6 & $\begin{array}{l}\text { saya mengalami kebingungan bagaimana membantu siswa-siswa } \\
\text { agar lebih bertanggungjawab. }\end{array}$ & 0.4 & 3.2 & 3.6 & 51.4 & 41.4 \\
\hline 7 & $\begin{array}{l}\text { Saya mengetahui bagaimana strategi bimbingan yang baik untuk } \\
\text { mengubah karakter siswa kearah yang positif }\end{array}$ & 29.6 & 56.4 & 10.0 & 3.2 & 0.8 \\
\hline 8 & $\begin{array}{l}\text { Saya tidak yakin melalui bimbingan \& konseling kepada siswa } \\
\text { menjadikan ia orang yang jujur. }\end{array}$ & 1.2 & 9.2 & 14.0 & 47.2 & 28.4 \\
\hline 11. & $\begin{array}{l}\text { Melalui layanan bimbingan dan konseling saya merasa mampu } \\
\text { memberi pengaruh yang positif dalam mengembangkan karakter } \\
\text { siswa yang kurang diperhatikan orang tuanya. }\end{array}$ & 15.2 & 61.6 & 17.2 & 4.8 & 1.2 \\
\hline 14 & $\begin{array}{l}\text { Kalau saya mempunyai siswa yang terus menerus berbohong, saya } \\
\text { akan dapat membuat dia menghentikan kebiasaan berbohong itu. }\end{array}$ & 3.6 & 34.3 & 37.3 & 23.4 & 0.8 \\
\hline 17 & $\begin{array}{l}\text { Saya sering mengalami kesulitan untuk meyakinkan kepada siswa } \\
\text { bahwa menghargai orang lain adalah penting. }\end{array}$ & 1.2 & 9.3 & 7.3 & 65.7 & 16.5 \\
\hline 19 & $\begin{array}{l}\text { Saya dapat mempengaruhi karakter siswa karena saya adalah } \\
\text { contoh yang baik bagi mereka. }\end{array}$ & 27.0 & 62.9 & 8.9 & 1.2 & 0.0 \\
\hline
\end{tabular}




\begin{tabular}{|c|l|c|c|c|c|c|}
\hline $\mathbf{2 1}$ & $\begin{array}{l}\text { Kadang saya tidak tahu apa yang harus dilakukan untuk } \\
\text { membimbing dan mengubah perilaku siswa agar menjadi lebih } \\
\text { peduli. }\end{array}$ & 0.4 & 11.7 & 17.0 & 58.3 & 12.6 \\
\hline $\mathbf{2 3}$ & $\begin{array}{l}\text { Saya selalu berusaha untuk menemukan strategi bimbingan } \\
\text { terbaik untuk mengembangkan karakter siswa. }\end{array}$ & 19.5 & 58.9 & 17.5 & 2.4 & 1.6 \\
\hline
\end{tabular}

\section{B.2. Tingkat general Self Efficacy Konselor}

Tabel 2.2. Distribusi respon konselor untuk komponen persona self efficacy

\begin{tabular}{|c|c|c|c|c|c|c|}
\hline No & Pernyataan & SS & $\mathbf{S}$ & TT & TS & STS \\
\hline 4 & $\begin{array}{l}\text { konselor tidak memiliki tanggung jawab dalam menumbuhkan } \\
\text { sopan santun siswa. }\end{array}$ & 0.4 & 2.4 & 8.1 & 53.2 & 35.9 \\
\hline 5 & $\begin{array}{l}\text { Ketika siswa memiliki sikap hormat kepada orang lain, hal } \\
\text { tersebut disebabkan karena saya sebagai konselornya telah } \\
\text { member contoh yang baik bagaimana menghormati orang lain. }\end{array}$ & 30.1 & 50.2 & 16.1 & 2.8 & 0.8 \\
\hline 9 & $\begin{array}{l}\text { Siswa yang rajin seringkali karena kontribusi konselor } \\
\text { memberikan bimbingan untuk mengerjakan dan bertanggung } \\
\text { jawab akan tugas-tugasnya. }\end{array}$ & 18.1 & 60.2 & 15.3 & 5.6 & 0.8 \\
\hline 10 & $\begin{array}{l}\text { konselor yang bersungguh-sungguh mendorong siswanya untuk } \\
\text { menghormati orang lain akan melihat adanya peningkatan } \\
\text { kemampuan siswa ketika berinteraksi dengan orang lain. }\end{array}$ & 0.8 & 4.8 & 3.6 & 54.0 & 36.8 \\
\hline 12 & $\begin{array}{l}\text { Jika orang tua lebih bertanggungjawab dan memberi perhatian } \\
\text { kepada anaknya, hal itu yang akan dapat membuat konselor } \\
\text { mengembangkan karakter siswanya. }\end{array}$ & 3.3 & 53.7 & 35.4 & 7.7 & 0.0 \\
\hline 13 & $\begin{array}{l}\text { Siswa tidak akan memiliki sikap respek pada orang lain jika } \\
\text { mereka tidak memiliki konselor yang dapat meningkatkan sikap } \\
\text { tersebut. }\end{array}$ & 7.3 & 62.9 & 12.1 & 14.1 & 3.6 \\
\hline 15 & $\begin{array}{l}\text { Jika siswa tidak memiliki sikap sopan santun, itu karena } \\
\text { konselor tidak cukup mampu menjadi contoh bagi mereka. }\end{array}$ & 12.1 & 52.4 & 18.5 & 14.5 & 2.4 \\
\hline 16 & $\begin{array}{l}\text { Jika sikap tanggungjawab tidak ditumbuhkan dalam keluarga } \\
\text { maka konselor akan tidak berhasil menanamkan nilai-nilai } \\
\text { tersebut di sekolah. }\end{array}$ & 3.7 & 19.9 & 24.0 & 47.2 & 5.3 \\
\hline 18 & $\begin{array}{l}\text { Ketika seorang siswa menjadi lebih peduli orang lain, biasanya } \\
\text { hal tersebut karena guru-guru dan konselornya menciptakan } \\
\text { ikilm yang peduli kepada orang lain di sekolah. }\end{array}$ & 14.7 & 65.7 & 17.6 & 2.0 & 0.0 \\
\hline 20 & $\begin{array}{l}\text { Seorang konselor yang mengajarkan kejujuran dalam proses } \\
\text { bimbingan dan konseling pada akhirnya akan menghasilkan } \\
\text { siswa yang lebih jujur. }\end{array}$ & 10.0 & 32.7 & 23.7 & 5.7 & 0.0 \\
\hline 22 & Saya merasa bersalah ketika siswa saya tidak jujur. & 0.0 & 3.3 & 8.5 & 50.8 & 37.4 \\
\hline 24 & $\begin{array}{l}\text { Konselor yang mendorong siswanya untuk bertanggung jawab di } \\
\text { sekolah dapat mempengaruhi tingkat tanggung jawab siswa di } \\
\text { luar sekolah. }\end{array}$ & 23.4 & 64.9 & 9.3 & 2.0 & 0.4 \\
\hline
\end{tabular}

Dari tabel tersebut diatas dapat diketahui rata-rata respon terhadap skala Character Education Efficacy Belief Instrumen (CEEBI). Nilai rata-rata respon terhadap 12 item Persona Eficacy Conselor (PEC) sebesar 48, 58. Sedangkan nilai ratarata respon terhadap 13 item General Eficacy Conselor (GEC) sebesar 45.34.

Tabel 2.1 menunjukkan responrespon terhadap 12 item PEC. Respon positif paling banyak diberikan oleh responden terhadap item no 3 (Saya sangat yakin telah menjadi contoh yang baik bagi murid-murid saya), disusul kemudian dengan item no1 (Saya merasa nyaman membicarakan tentang perilaku baik dan buruk dengan murid-murid saya). Sedangkan sebanyak 92.2\% responden menyatakan tidak setuju dan sangat tidak setuju untuk merespon item no 6 (saya mengalami kebingungan bagaimana membantu siswa-siswa agar lebih bertanggungjawab). Dari tabel 4.2 dapat diketahui bahwa sebanyak 37. 5\% responden mengalami dilematik dalam merespon item no 14.

Distribusi respon-respon terhadap GEC dijelaskan pada tabel 2.2. Pada tabel tersebut respon positif setuju terbanyak pada item no 18 yang menyatakan "Ketika seorang siswa menjadi lebih peduli orang lain, 
biasanya hal tersebut karena guru-guru dan konselornya menciptakan ikilm yang peduli kepada orang lain di sekolah". Sedangkan respon negatif terbanyak ada pada item no 10 sebanyak 54\% (konselor yang bersungguhsungguh mendorong siswanya untuk menghormati orang lain akan melihat adanya peningkatan kemampuan siswa ketika berinteraksi dengan orang lain) dan pada item no 22 sebanyak 50.8\% (Saya merasa bersalah ketika siswa saya tidak jujur.)

Dalam berbagai kajian literature pendidikan karakter menjadi bagian penting pengembangan karakter bangsa melalui pendidikan. Karakter bangsa akan terbentuk sesuai dengan keunikan dan identitas bangsa manakala keterlibatan struktur pemerintah memberikan kebijakan pentingnya semua elemen masyarakat terlibat aktif. Secara khusus, lembaga pendidikan yang secara terencana menangani pengajaran formal. Istilah yang cukup populer adalah pendidikan karakter mempunyai peran penting di tengah transisi sistem demokrasi yaitu dari proses mengambil kebijakan masalah-masalah nasional bersifat top down menuju buttom up. Implikasi perubahan struktur pemerintahan berpengaruh pada perubahan budaya masyarakat. Perubahan terletak menjamurnya kegiatan keagamaan yang bersifat ekstrim maupun radikal. Kekerasan dalam hubungan antar agama, dan kegiatan asusila yang muncul kepermukaan di daerahdaerah perkotaaan secara bebas.

Dari hasil survey ini menunjukkan secara umum bahwa konselor sekolah memiliki tingkat self efficacy yang tinggi untuk dapat mengembangkan pendidikan karakter. Hal ini ditunjukkan dengan tingginya skor respon terhadap CEEBI. Konselor sekolah yang memiliki self efficacy tinggi akan memiliki keyakinan untuk mampu melakukan tugas mengembangkan karakter siswa. Seperti yang dikemukakan oleh Bandura (1997) bahwa Self-efficacy merupakan kepercayaan pada satu kemampuan untuk mengatur dan melaksanakan bagian dari aktivitas yang dibutuhkan untuk menghasilkan tujuan yang diinginkan (Bandura, 1997). Self-efficacy merupakan suatu keyakinan dalam diri seseorang bahwa ia mampu melakukan tugas tertentu. Keyakinan akan self-efficacy mempengaruhi pemilihan perilaku, usaha, dan ketekunan seseorang. Self-efficacy dapat menentukan bagaimana perasaan seseorang, cara berfikir, dan berperilaku (Bandura, 1997).

Konselor dengan self-efficacy yang tinggi cenderung untuk mencoba metodemetode bimbingan, mencari metode alternatif, dan melakukan percobaan dengan materi bimbingan yang efisien dan inovatif. Konselor sekolah yang memiliki self-efficacy yang tinggi juga akan lebih mengembangkan aktivitas yang menantang, membantu siswa untuk sukses, dan bertahan dengan siswa yang mengalami masalah dalam belajar. Konselor sekolah dengan self-efficacy yang tinggi menyukai lingkungan sekolah yang positif, mendukung ide-ide siswa, dan menanyakan hal-hal yang dibutuhkan oleh siswa. Teori self-efficacy memprediksikan bahwa konselor sekolah dengan self-efficacy tinggi bekerja lebih keras dan bertahan lebih lama ketika menghadapi siswa yang mengalami kesulitan belajar. Hal ini karena konselor sekolah percaya pada dirinya dan siswa-siswanya (Pintrich, 2002).

Bila dijabarkan lebih rinci tingkat self efficacy yang tinggi pada konselor konselor sekolah di Kota Malang untuk mengembangkan karakter siswa sangat relevan dengan tingkat keyakinan mereka untuk menjadi model karakter bagi siswanya. Hal ini dapat dilihat dari skor untuk aspek Model Karakter (lihat Tabel 2.1) yang ratarata berada pada tingkat cukup tinggi. Namun demikian, meskipun dari tabel dapat diketahui bahwa secara rinci keyakinan konselor sekolah dalam mengembangkan karakter siswa menunjukkan bahwa mereka memiliki self efficacy yang tinggi dalam mengembangkan karakter jujur, respek, dan bertanggung jawab, namun secara keseluruhan self efficacy konselor sekolahkonselor sekolah untuk menjadi model karakter bagi siswanya masih lebih rendah dari pada keyakinan terhadap kemampuan mengembangkan karakter jujur, respek, dan bertanggung jawab. Temuan ini menunjukkan bahwa secara umum, konselorkonselor sekolah merasa sedikit tidak yakin atau ragu-ragu terhadap kemampuannya untuk menjadi model karakter. Sehingga hal ini sesuai dengan skor pada aspek model 
karakter lebih banyak pada tingkatan cukup tinggi. untuk berbagai macam karakter dan keyakinan untuk dapat mengubah karakter siswa.

Berdasar data yang telah terkumpul dan dianalisa, tingginya tingkat self efficacy konselor sekolah untuk mengembangkan pendidikan karakter dipengaruhi oleh beberapa faktor yang memberikan kontribusi terhadap tingginya self efficacy konselor sekolah. Dari aspek demografi menunjukkan bahwa pendidikan responden yang sebagian besar mengenyam pendidikan S1 dan beberapa S2 turut menentukan tingginya self efficacy konselor sekolah. Selama pendidikan, konselor sekolah-konselor sekolah PAI memiliki banyak pengalaman yang dapat meningkatkan Self efficacy

Faktor lain yang juga memberikan peran meningkatkan self efficacy adalah pengalaman menjadi konselor di atas 15 tahun dan usia responden paling banyak berusia diatas 35 tahun,. Menurut Bandura salah satu pembentuk self efficacy seseorang adalah pengalaman yang memberikan perasaan keberhasilan dan kegagalan pada diri sesorang. Di mana pengalaman-pengalaman tersebut akan membentuk harapanharapan ketika sesorang mengahadapi situasi yang baru. Pengalaman adalah sumber yang paling penting bagi berkembangnya selfefficacy

\section{Implikasi bagi Pendidikan Konselor sekolah}

Dari hasil penelitian ini menunjukkan bahwa konselor sekolah memiliki self efficacy yang tinggi dalam mengembangkan karakter siswa. Hal ini tidak terlepas dari pendidikan konselor sekolah yang mereka tempuh di mana ikut berpengaruh terhadap keyakinan mereka sebagai konselor sekolah yang mampu menjadi model dan mengubah karakter siswa menjadi karakter yang lebih baik. Temuan ini sangat sesuai dengan hasil penelitian yang dilakukan oleh Jones, Ryan, dan Bohin (1998). Hasil temuan penelitian mereka menyatakan bahwa proses pendidikan konselor mempengaruhi terbentuknya efficacy pada calon konselor untuk menjadi model bagi pengembangan karakter klien (siswa) dan menekankan calon konselor memiliki "komitmen" yang lebih besar untuk pendidikan karakter dan program-program spesifik untuk mengembangkan karakter masyarakat.

Jika pendidikan memberikan kontribusi penting bagi pengembangan self efficacy konselor sekolah, maka menjadi tanggung jawab LPTK-LPTK yang membuka jurusan bimbingan dan konseling untuk menigkatkan kualitas layanan pendidikan serta kualitas mutu pendidikan sehingga menghasilkan konselor sekolah-konselor sekolah yang memiliki kemampuan untuk menjadi konselor sekolah-konselor sekolah yang professional. Kemampuan-kemampuan tersebut akan memberikan rasa percaya diri bagi lulusan-lulusan LPTK untuk yakin bahwa mereka dapat menjadi konselor sekolah yang baik serta model karakter bagi siswa-siswanya.

Hasil penelitian ini hanya terbatas pada konselor sekolah yang ada di Kota Malang.. Oleh karena itu perlu ada penelitian lanjutan dengan responden berasal dari berbagai macam karakter dan latar belakang. Sehingga dapat diketahui lebih banyak informasi apakah faktor-faktor yang mempengaruhi keyakinan yang tinggi konselor sekolah. mengembangkan karakter siswa.

Secara teoritis, penelitian ini penting sebagai 1) landasan bangunan epistemologi konselor tentang pentingnya peningkatan kompetensi konselor sekolah dalam mengembangkan karakter peserta didik, 2) bagi Fakultas Keguruan dan Ilmu Pendidikan sebagai LPTK, penelitian ini berguna untuk mendesain kurikulum Bimbingan dan Konseling untuk meningkatkan kompetensi konselor sekolah berbasis karakter.

Secara praktis, penelitian ini berguna untuk 1) sebagai masukan bagi pengambilan kebijakan yang berkaitan dengan pengembangan pendidikan karakter siswa, 2) hasil penelitian dapat menjadi input pengembangan program-program pelatihan peningkatan kompetensi konselor sekolah.

\section{PENUTUP}

Dari hasil temuan penelitian ini menunjukkan bahwa konselor sekolah memiliki self efficacy yang tinggi untuk mengembangkan karakter siswa. Self efficacy yang tinggi ini memberikan perasaan mampu 
untuk memberikan pendidikan karakter. Ada banyak faktor yang diperkirakan menjadi prediktor terhadap tingginya self efficacy konselor sekolah, antara lain pendidikan konselor sekolah yang telah ditempuh pada jenjang S1 bahkan pada jenjang S2. Sehingga konselor memiliki keyakinan bahwa dirinya mampu untuk memberikan pendidikan karakter kepada siswa.

Faktor usia dan pengalaman juga memberikan kontribusi tingkat self efficacy konselor sekolah terhadap kemampuannya menjadi pendidik karakter. Walaupun secara umum persentase menjadi model karakter lebih rendah dibandingkan pengembangan karakter yang lain, namun secara individual setiap konselor memiliki keyakinan bahwa dirinya mampu menjadi model karakter bagi siswa. Hal ini ditunjukkan dengan tingginya persentase konselor dalam mengembangkan karakter-karakter yang lain.

Tingkat self efficacy yang tinggi pada konselor tidak terlepas dari proses pendidikan yang telah dikembangkan oleh LPTK-LPTK. Oleh sebab itu, peningkatan kualitas LPTK dalam menyelenggarakan pendidikan bagi konselor menjadi hal yang serius untuk diperhatikan karena lembagalembaga tersebut akan menghasilkan konselor yang menjadi ujung tombak bagi keberhasilan pendidikan karakter di Indonesia. Keberhasilan pendidikan karakter tentu saja akan memberikan kontribusi terhadap pembangunan bangsa Indonesia yang bermartabat dan berkarakter.

\section{Daftar Rujukan}

Bandura, A. (1997). Self-efficacy: unifying theory of behavior The exercise of control. New York: Free man. Bandura, A. (1986). Social foundations of thought and action. A social cognitive theory. Englewood Cliffs, NJ: Prentice-Hall. Dalam Skaalvik, E. M. and Skaalvik, S.(2007). Dimensions of Teacher Self-Efficacy and Relations With Strain Factors, Perceived Collective Teacher Efficacy, and Teacher Burnout. Journal of Educational Psychology, Vol. 99, No. 3, 611-625.
Bandura, A. (2006a). Adolescent development from an agentic perspective. In F. Pajares \& T. Urdan (Eds.), Self-efficacy beliefs of adolescents (pp.1-43). Greenwich, CT: Information Age.

Barnes, G.V, (2002 ). Self-Efficacy and Teaching Effectiveness. Journal of string research, Vol 1.

Guskey, T.R and Passaro, P.D.(2001). Teacher Efficacy: A Study of Construct Dimensions. American Educational Research Journal, Vol. 31, No. 3 , pp. 627-643

Gibson, S., \& Dembo, M. H. (1984). Teacher efficacy: A construct valida tion. Journal of Educational Psychology, 76(4), 569582.

Lickona, T. (1993). The return of character education. Educational Leadership, 611. McClellan,

Milson, A. J. (2000). Implementation of character education. Social studies teacher educators' perceptions Theory and Research in Social Education, 28, 144-169. Pub. L. No. 103-301, National Character Counts Week Proclamation of 1994, 108 Stat. 1558-1559 (1994).

Milson, A.J and Mehlig, L.M.(2002). Elementary School Teachers' Sense Of Efficacy For Character Education. The educational research, Vol. 96, No 1, pp 47-53

Pintrich, Paul R (2002) Motivation in Education Theory, Research and Aplication. $2^{\text {nd }}$ Edition. New Jersey. Merill Prentice Hall.

Salomon, G. (1983). The difTerential invest- ment of mental effort in learning from dif-ferent sources. Educational Psychologist, 18, 42-51 
Schunk, D. H., \& Meece, J. L. (2006). Self-efficacy development in adolescence. In Skaalvik, E. M. and Skaalvik, S.(2007). Dimensions of Teacher Self-Efficacy and Relations With Strain Factors, Perceived Collective Teacher Efficacy, and Teacher Burnout. Journal of Educational Psychology, Vol. 99, No. 3, 611-625.

Skaalvik, E. M. and Skaalvik, S.(2007). Dimensions of Teacher Self-Efficacy and Relations With Strain Factors, Perceived Collective Teacher Efficacy, and Teacher Burnout. Journal of Educational Psychology, Vol. 99, No. 3, 611-625.

Singarimbun, M. (1998). Metodologi penelitian survey: Pustaka LP3ES, Jakarta

Suyata .(2011). Pendidikan Karakter: Dimensi Filosofis. Dalam Pendidikan Karakter dalam Perspektif Teori dan Praktik. Yoyakarta; UNY Perss.

Zamroni. (2011). Strategi dan Model Implementasi Pendidikan Karakter di Sekolah. Dalam Pendidikan Karakter dalam Perspektif Teori dan Praktik. Yoyakarta; UNY Perss.

Woolfolk, A. E., \& Hoy, W. K. (1990). Prospective teachers' sense of efficacy and beliefs about control. Journal of Educational Psychology, 82, 81-91.

Wynne, E. A. (1997). For-character education. In A. Molnar construction of (Ed.), The children's character: Ninetysixth yearbook of the National Society for the Study of Education, part two (pp. 63-76). Chicago: The University of Chicago Press. 